\title{
Building community partnerships
}

\section{The "One Book, One Community" experience}

\author{
by Mae L. Rodney
}

$\mathrm{H}$

ow do librarians get young adults to read

a classic novel or an inspiring biography? How can libraries compete with the lure of new technologies and the entertainment industry for the attention of young minds?

These are some of the questions today's librarians are asking themselves and attempting to answer with new programming. To bring patrons into the library, some libraries have imitated bookstores by setting up coffee shops and setting aside sections for popular books and videos.

"One Book, One Community" draws patrons into the library and heightens interest in reading and discussion by choosing a single work (often a novel or play) for discussion by established groups or by new groups formed for the purpose of the discussion.

The one book, one community concept has proven to be successful in building a sense of belonging to a community, encouraging the formation of new communities, and, in some instances, opening up communication on sensitive issues

Adopting the one book, one community experience within the academic environment can foster community among students, librarians, faculty, and administrators. Students are often unaware of the many research resources university libraries provide, and if faculty members do not include library/research activities in their course syllabus, academic libraries can easily become store- houses rather than centers of leaming. The one book, one community approach gives students new research topics and varied opportunities to build critical thinking, creative writing and oral communication skills, while at the same time providing exciting and intellectually stimulating experiences that will encourage reading and open discussion and debate beyond the classroom.

\section{Bringing "One Book, One Community" to campus}

This approach has been used very successfully at Winston-Salem State University (WSSU), a small historically black liberal arts institution with a rich 110-year history that includes being the first African American college chartered (1925) to offer a degree in elementary education. Throughout its history, the university has expanded to offer new instructional programs and higher degree levels, including, since 2000 , master's degree-level programs in business, computer science, elementary education, nursing, and physical therapy. Enrollment has grown from 25 students in 1892 to 4,100 in 2003-04. To better serve this thriving community, the library staff has embraced technology. Significant advancements have been made in library programming for the last five years, including creating a wireless environment with more than 100 public access computers located throughout the building and supporting an environment where siudents can conduct library research from

\section{About the author}

Mae L. Rodney is director of library services at Winston-Salem State University, e-mail: rodneym/@wssu.edu

(C) 2004 MaeL.Rodney 
any location on or off campus with Internet access. Library programs include a multitiered library instruction progtam, a brown-bag lunch series, a fall and spring book discussion session, as well as an annual benefit.

For the last four annual library benefits, the library has collaborated with the WSSU Drama Guild to spotlight African American writers with mini theatrical productions. This year the Drama Guild director recommended featuring Lorraine Hansberry and her play "What Use Are Flowers?"

To focus the university's attention on the fundraiser and meet the 2003-04 benefit's goal of increasing student participation and faculty attendance, the library director recommended asking all faculty and students to read and discuss "What Use Are Flowers?" Merging the book discussions and the library benefit in this way would ensure that several segments of the Winston-Salem community would read and explore the same AfricanAmerican writer and book.

The library staff had long wanted to expand student's reading materials because university reading requirements were fairly prescribed. Several upbeat "one book" presentations and conversations by the library director were necessary to encourage many campus groups to read the play, discuss the thoughtprovoking script, and learn more about an African American literary icon. The presentations helped form new partnerships to involve the entire university community.

The provost set a precedent when he approved and adopted the concept as a campuswide activity. He recommended that the campus bookstore and student government association become partners and offered his financial support to advertise the project. The bookstore became an important agent when prospective students came to campus during the summer for preregistration sessions and wanted to purchase the book while they were on campus. In almost every instance, another partnership was formed after a new presentation.

Several large campus groups -incoming freshman, English classes, education, and nursing majors-were selected as the primary potential participants in the one book, one community experience during the initial planning process. Leaders of the targeted groups were identified. A Web site with a study guide, list of activities, and a short biography of the author was created and posted. The experience of reading the short play and researching Hansberry's life and political beliefs was enriched by a variety of fall activities — a lecture, reader's theater, book discussion, and a mini theatrical production for the annual library benefitand a further array of spring activities, including a faculty presentation, a full production of the play, and a writing contest.

\section{First-year college, freshman seminar and learning communities}

The strongest initial partnerships were formed with first-year college coordinators who had established personnel clusters, schedules and programs, where information could be readily shared and incorporated. The coordinators endorsed the reading project as an excellent new leaming experience that could be shared with parents during orientation sessions for prospective students. The firstyear college coordinators viewed the reading experience as a positive leaming opportunity that would be well received by parents. Following this endorsement, and presentations during summer orientation sessions, several parents of prospective students became participants in the experience.

Faculty members were informed about the "What Use Are Flowers?" reading experience through presentations to freshman experience faculty, administrative retreats, and general faculty meetings. The study guide for the play offered discussion questions under a number of subjects and was used to help faculty members visualize how a discussion of "What Use Are Flowers?" could easily be woven into a syllabus. Presentations also illustrated how learning communities (nursing, education, business, etc.) could benefit from reading the play. For example, nursing students could research and discuss the medical implications of a nuclear catastrophe, while education majors could consider the impact of children growing up without adults.

Some questions in the study guide encouraged critical thinking and exploration of current topics, such as the war in Iraq or the ethics of war. The study guide was always distributed during presentations. To get upper-level students involved, all faculty members were invited to lead at least one class discussion on a relevant topic from the study guide. An education faculty member who had used the play as a project during summer session endorsed the venture and encouraged faculty to include such assignments in their classes. The one book, one community experience was emphasized as a way to build students' reading habits, to extend students' exposure to litera- 
The one book, one community

concept has proven to be

successful in building a sense of

belonging to a community.

encouraging the formation of new

communities, and, in some

instances, opening up

communication on sensitive

issues.

ture beyond their textbooks, and to help students develop friendships by fostering the development of study groups during their initial days at the university. These were all established objectives of the learning communities.

Several faculty members went beyond the basic expectation of requiring students to read and discuss the play. A marketing professor required her students to compile an innovative marketing plan, which included the concepts from "What Use Are Flowers?" as well as marketing concepts, environmental analysis, sample promotional items, marketing objectives, and other marketing techniques. The library's associate director partnered with this class and served as the evaluator for the students' end-of-semester presentations.

A different experience occurred in a "Social Work as a Profession" class. In this class students discussed the impact of violence on society, violence as a primary issue in the social work environment, and how positive reinforcement can counteract aggression. 'The students created a partnership with the library's artist in residence to present a short play on violence during the spring semester. The university's Center for Community Safety has been invited to cosponsor the production and invite their community partners to discuss the impact of violence on children and communities.

\section{Lyceum committee}

The Lyceum/Hall-Patterson Lecture Series committee was approached to sponsor a fall lecture on "What Use Are Flowers?" Working with this committee, a long-established group with an effective routine for recruiting an audience, was easy and effective and eliminated the need to create a new lecture time that would conflict with established routine. The library staff was responsible only for identifying, communicating with, and hosting the lecturer. Having an outside guest lecturer offered an even broader perspective on Lorraine Hansberry. To provide students the opportunity to hear local faculty beyond the classroom, a WSSU psychology professor who lectures nationally will discuss the impact of war on children during the spring semester as part of the library's Brown Bag Lecture Series. The objective of these discussions is to examine issues in the play in as many forums and formats as possible.

\section{The library and the one book experience}

The library staff participated in the one book, one community experience through the library instructional sessions scheduled during the freshman experience course. Several assignments on "What Use Are Flowers?" and Hansberry were created to further extend students' awareness of the author and play, while helping students develop library and research skills. The assignments were specifically designed to reinforce the instruction. The students benefited from this experience because they had a specific assignment to complete.

Several displays about the author and play were posted throughout the library to keep Hansberry and "What Use Are Flowers?" in the forefront of the community's mind. A Web site that included the basic information required to begin a discussion on either the book or the author was posted and could be accessed from the library's homepage.

When the university Drama Guild presented a mini theatrical production of segments of "What Use Are Flowers?" and other Hansberry works during the library's annual benefit, the audience was fascinated to learn about Hansberry's political beliefs and see that her message was still relevant. A vicleotape of the mini-production will be broadcast via the campus TV station during Black History month, and during the spring semester the Drama Guild will present the full production of the play for the student body.

All freshman composition classes will read and discuss the play during the spring. The WSSU Friends of the Library became the partner for this assignment by providing the funds to purchase photocopying privileges for the play so all students could have a copy. It is hoped that some students will be inspired to submit a narrative, song, poem, or other reaction through art during the spring writing contest. Students wrote 


\section{The ACM Digital Library}

\section{The Ultimate Online INFORMATION TECHNOLOGY Resource!}

Discover the ACM Digital Library in the ACM Portal, a vast online resource of ACM's computing and information technology publications. Your patrons can enjoy unlimited access to more than one million pages of full text with archives dating back to the 50 's. This unparalleled resource is a must-have for every technology collection!

The ACM Digital Library includes:

- Over 30 ACM publications, plus conference proceedings

- $48+$ years of archives

- Advanced searching capabilities

- 1.2 million pages of downloadable text

Plus, over 750,000 bibliographic citations are available in the ACM Online Guide

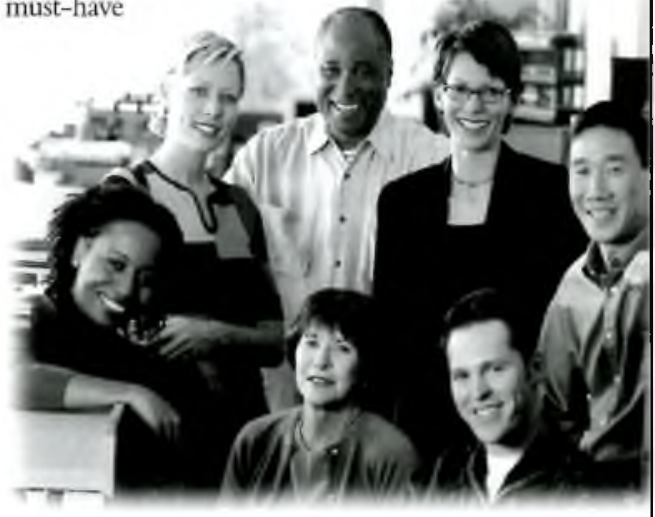

\section{AN EXCEPTIONAL VALUE}

\section{FREE G IFT}

Contact ACM and receive a FREE GIFT* for inquiring about the ACM Digital Library for your institution (while supplies last). Please mention code $\mathrm{ADCH} 24$.

* Limited to one per institution/organization

\section{acm}

Association for Computing Machinery The First Society in Computing
ACADEMIC INSTITUTIONS, please contact:

ACM Member Services

e-mail: acmhelp@acm.org

phone: $+1-212-626-0500$

fax: +1-212-944-1318

CORPORATIONS \& CONSORTIA, please contact:

DL Coordinator

e-mail: dl-info@acm.org

phone: +1-212-626-0518

fax: +1-212-944-1318

www.acm.org/dl 
tion, "Don't these people use the library?" We know they do use the library, but as ad hoc users, students cannot possibly be asked to know the lingo of libraries. That is not to say that students do not need to understand the various concepts behind the terminology, but that they need not become "little librarians."

Students are already bogged down with new terminology from their courses and a new way of life (leaving home and coming to college). Why should they be burdened with trying to learn yet another set of terms that they see no need for understanding? What is driving them to understand this terminology? While we seek answers to these and similar questions, we need to find a way to explain library collections and systems to our students while minimizing the use of "library lingo."

Compounding this issue, our students come from more diverse backgrounds than ever before and no two students have the same baseline knowledge of libraries. Many have never set foot in their high school library and some may not have had a high school library to use at all. Many may have used their library but never needed to know the finer points of library lingo. They had no rea- son to do so then, and we believe they really shouldn't be expected to do so in college.

\section{Learning, not lingo}

Perhaps we can find a way to put an end to the heavy use of library lingo in our reference transactions and in our instruction sessions. By no means do we have the answers to this problem right now Many libraries already recognize this problem and have created guides to library lingo for their students (some examples are listed above). We hope to come up with other solutions to this problem with an investigation we are about to begin. We plan on surveying students at the University of North Carolina-Wilmington to find out which libraryrelated terms our students do understand and which ones they do not.

Once we collect this information, we will make sure that all our library staff and faculty are aware of the terms that we all use that are meaningful to our students, and we also hope to share our findings with the profession as a whole. Hopefully, we will be able to better communicate with them and actually teach them only that which they really need to know: how to obtain and evaluate information.

\section{("Building community..." continued frompage 132)} memories and songs during the summer and fall after reading and discussing the play.

Although the schedule of activities has not been completed, conversations with a cross-section of university faculty members who created unique assignments are being held regarding selecting the next book and enhancing the learning experiences.

An English teacher is interested in improving critical thinking activities and getting more faculty to buy into the experience. Another idea is to choose a book by an author who can visit campus and participate in the discussions, thus increasing the glamour of and adding interest to the experience. Also being discussed are determining the best time to present the new title to the faculty in order to ensure that more faculty plan class activities and the need to give administrators an oppor- tunity to lead a discussion to ensure that they do more than just endorse the concept.

The one book, one community experience has not increased the number of books checked out of the O'Kelly Library collection, but because of an aggressive library instruction program and assignments given when instruction is provided, the number of students coming to the reference desk seeking assistance with their assignments has increased.

Projects such as "One Book, One Community" enrich and extend the WSSU learning environment and illustrate to faculty that the library is an innovative campus agency. As a result of advertising their services, projects and availability, librarians are being seen outside of the library. Because of their demonstrated willingness to actively participate in learning experiences, maybe librarians will be given new opportunities to partner in the entire learning process. 